\title{
PERBANDINGAN PROFIL KADAR IL-5 DAN JUMLAH EOSINOFIL PADA PETANI YANG TERINFEKSI SOIL TRANSMITTED HELMINTH DI DUSUN SUMBERAGUNG KECAMATAN GURAH DAN DUSUN JANTI KECAMATAN PAPAR KABUPATEN KEDIRI
}

\author{
Siska Kusuma Wardani ${ }^{1}$, Prof. Dr. Suwarno, drh., M.Si ${ }^{2}$, \\ Heny Arwati, Dra., M.Sc., Ph.D ${ }^{3}$ \\ Program Studi S2 Imunologi, Sekolah Pascasarjana, Universitas Airlangga \\ Surabaya \\ E-mail: siskakusuma84@gmail.com
}

\begin{abstract}
ABSTRAK
Soil Transmitted Helmint (STH) merupakan cacing tanah golongan nematoda yang penularannya melalui tanah. Cacing yang banyak menginfeksi manusia adalah Ascaris lumbricoides, Trichiuris trichiura, cacing tambang. Insiden tinggi ditemukan pada petani yang langsung berhubungan dengan tanah.Respon imun hospes terhadap infeksi cacing dimulai dengan teraktifasinya Th2 dengan peningkatan yang signifikan dari IL-4, IL-5, IL-9, IL-10 dan IL-13. Sitokin IL-5 yang terbentuk merangsang perkembangan dan aktivasi eosinofil. Tujuan penelitian ini adalah mengetahui peningkatan kadar IL-5 dan jumlah eosinofil pada petani yang terinfeksi STH di Dusun Sumberagung Kecamatan Gurah dan Dusun Janti Kecamatan Papar Kabupaten Kediri. Telah dilakukan penelitian secara cross sectional terhadap 20 orang yang terinfeksi STH dan 20 orang yang tidak terinfeksi STH. Spesimen feses, darah dan serum dengan pemeriksaan feses secara mikroskopis, kadar IL-5 metode ELISA dan jumlah eosinofil secara hematology analyzer.

Data analisis dengan uji $\mathrm{t}$ independent dengan hasil statistik bermakna bila $\mathrm{p}<0,05$. Didapatkan kadar kadar IL-5 pada petani yang terinfeksi STH 5,7 $\mathrm{pg} / \mathrm{ml}$ dan jumlah eosinofil 4,45\%. Pada hasil korelasi kadar IL-5 dan jumlah eosinofil pada petani yang terinfeksi STH di dapatkan hasil $\mathrm{p}=0,001<0,05$ dan jumlah eosinofil $\mathrm{p}=0,014<0,05$ dapat di simpulkan bahwa kadar IL-5 dan jumlah eosinofil berpengaruh terhadap petani yang terinfeksi STH. Pada hubungan jenis spesies dan jumlah spesies dengan kadar IL-5 dan jumlah eosinofil tidak menunjukkan perbedaan pada infeksi tunggal, baik pada A. lumbrocoides, T.trichiura, Hookworm dan juga pada infeksi ganda A. lumbrocoides dan T.trichiura
\end{abstract}

Kata Kunci. Soil Transmitted Helminth (STH), petani, eosinofil, IL-5 


\begin{abstract}
Soil Transmitted Helmint (STH) are earthworms class nematodes is transmitted by the ground. Worms are a lot of infect humans is Ascaris lumbricoides, Trichuris trichiura, Hookworm. High incidence found in farmers who are directly in contact the ground. The immune response of host to worm infections begins with the activation of Th2 with the significant increase of IL4, IL-5, IL-9, IL-10, and IL-13. Cytokine IL-5 is formed to stimulating the development and activity of eosinophils. The purpose of this study is determine the increase of IL-5 and eosinophils count in the farmers infected by the STH in the Sumberagung village Gurah districts and Janti village Papar districts in Kediri counties. It has been done by cross sectional study on 20 people infected by the STH and 20 people who are not infected by the SHT. Speciment feces, blood and serum, by macroscopic examination of feces, levels IL-5 by ELISA method and eosinophils count by hematology analyzer.

Data analysis by independent test with the result of statistically significant when $\mathrm{p}<0,05$. Obtained levels of IL-5 on farmers infected by the STH $5,7 \mathrm{pg} / \mathrm{ml}$ and eosinophils count $4,45 \%$. On the results of the correlation levels of IL-5 and eosinophils count on farmers infected by the STH $\mathrm{p}=0,001<0,05$ and eosonophils $\mathrm{p}=0,014<0,05$. Can be concluded that levels of IL-5 and eosinophils count affect the farmers who are infected by the SHT. On the relationship of species and species count with levels of IL5 and eosinophils count showed that no difference in single infection, by on $A$. lumbricoides, T. trichiura, Hookworm and also the double infection A. lumbricoides and T.trichiura.
\end{abstract}

Key word : Soil Transmitted Helminth (STH), farmers, eosinophil, IL-5 


\section{PENDAHULUAN}

Infeksi kecacingan yang disebabkan oleh Soil Transmitted Helminth (STH) merupakan masalah kesehatan masyarakat Indonesia. Infeksi kecacingan tergolong penyakit infeksi yang kurang diperhatikan dan bersifat kronis tanpa menimbulkan gejala klinis yang jelas dan dampak yang ditimbulkannya baru terlihat dalam jangka panjang. Beberapa dampak yang disebabkan oleh cacing seperti kekurangan gizi, gangguan tumbuh kembang dan gangguan kognitif pada anak, dan apabila pada orang dewasa akan menurunkan produktifitas kerja (Kurniawan, 2010).

Tingginya infeksi STH masih merupakan permasalahan kesehatan di banyak daerah di dunia. Diperkirakan bahwa lebih dari dua milyar orang di dunia terinfeksi STH. Sekitar lebih dari dua milyar orang di dunia terinfeksi STH. Sekitar lebih dari satu milyar orang terinfeksi oleh Ascaris lumbricoides, 795 juta orang terinfeksi cacing tambang (Ancylostoma duodenale dan Necator americanus), dan Asia Tenggara merupakan salah satu wilayah yang memiliki prevalensi tinggi infeksi STH di dunia.

Prevalensi cacing tersebut tinggi terjadi didaerah tropis, karena telur dan larva cacing lebih dapat berkembang di tanah yang hangat, basah atau lembab. Perilaku juga memberikan kontribusi terhadap kejadian cacing misalnya hygiene dan sanitasi yang rendah pada suatu komuditas atau kelompok masyarakat.

Jenis cacing STH yang sering menginfeksi adalah Ascaris lumbricoides (cacing gelang), Trichuris trichiura (cacing cambuk), Necator americanus dan Ancylostoma duodenale (cacing tambang) ini disebabkan oleh karena kebiasaan dan perilaku yang tidak bersih misalnya; tidak mencuci tangan sebelum makan, kuku tangan panjang dan tidak pernah memakai alas kaki jika sedang melakukan aktifitas sehingga kebersihan kurang diperhatikan.
Faktor pemicu lain terjadinya infeksi cacing yakni faktor cuaca. Indonesia memiliki iklim tropis dengan musim hujan dan musim kemarau. Musim penghujan membuat tanah menjadi lembab dan menjadi faktor pendukung untuk berkembangnya telur cacing menjadi infektif. Penyakit kecacingan atau biasa disebut cacingan kurang mendapat perhatian yang cukup oleh sebagian besar masyarakat Indonesia

Insidens tinggi ditemukan pada penduduk Indonesia, terutama di daerah pedesaan, khususnya pada petani. Seringkali golongan petani yang langsung berhubungan dengan tanah, mendapat infeksi lebih dari $70 \%$. Kebiasaan defekasi di tanah/sungai dan pemkaian kotoran sebagai pupuk penting dalam penyebaran infeksi. Penularan Nematoda STH tidak hanya menular melalui tanah tetapi dapat melalui kotoran, adapun spesies dari golongan ini adalah cacing gelang (Ascaris lumbricoides), cacing tambang (Necator americanus dan Ancylostoma duodenale), cacing cambuk (Trichuris trichiura). Mekanisme penularan STH berkaitan dengan hygiene dan sanitasi lingkungan yang buruk, aspek sosial ekonomi dan tingkat pengetahuan seseorang.

Lawrence (2003), menjelaskan bahwa fungsi dari Interleukin 5 (IL-5) dan eosinofil adalah sebagai pelindung terhadap paparan berulang oleh parasit usus. Persentasi sel eosinofil ke jalur peradangan pada saluran pencernaan tergantung pada berbagai respon sitokin khususnya Th2. IL5 bertindak lebih cepat untuk meningkatkan sirkulasi eosinofil dengan pergerakan cara marginasi. Bahwa terjadinya peningkatan kadar IL-5 dan jumlah eosinofil akibat infeksi dari jenis cacing usus.

Selanjutnya akan di lakukan analisis mengenai hubungan antara peningkatan jumlah eosinofil dan kadar IL-5 pada para petani yang positif terinfeksi STH untuk mengetahui imunitas para petani yang terinfeksi STH tersebut. 


\section{HEADING}

\subsection{Tinjauan Petani}

Menurut UU No.41 tahun 2009, petani didefinisikan sebagai warga Negara Indonesia beserta keluarganya yang mengusahakan lahan untuk komiditas pangan berkelanjutan.

Buruh tani adalah seseorang yang bergerak dibidang pertanian, terutama dengan cara melakukan pengolahan tanah dengan tujuan untuk menumbuhhkan dan memelihara tanaman (seperti padi, jagung, buah dan lain-lain), dengan harapan untuk memperoleh hasil dari tanaman tersebut untuk digunakan sendiri atau menjualnya kepada orang lain (Husodo, 2006).

\subsection{Tinjauan Tentang Kecacingan}

Cacingan atau sering disebut dengan kecacingan merupakan penyakit endemik dan kronik yang diakibatkan oleh cacing parasit dengan prevalensi yang tinggi, tidak mematikan, tetapi menggerogoti kesehatan tubuh manusia sehingga dapat berakibat menurunnya kondisi gizi dan kesehatan masyarakat.

Infeksi cacing pada umumnya masuk melalui mulut, atau langsung melalui luka di kulit. Cacing yang masuk dapat berupa telur, kista atau larva, yang ada di atas tanah terutama bila pembuangan kotoran atau tinja dilakukan dengan menggunakan sistem terbuka dan tidak memenuhi persyaratan hyginis. Saat telur cacing masuk ke dalam perut maka akan segera menetas dan segera menggerogoti tubuh penderita.

Manusia merupakan hospes definitif beberapa Nematoda usus (cacing perut), yang dapat mengakibatkan masalah bagi kesehatan masyarakat. Di antara cacing tersebut yang terpenting adalah cacing gelang (A. lumbricoides), cacing tambang ( $N$. americanus dan A. duodenale), dan cacing cambuk ( $T$. trichiura). Cacing tersebut banyak ditemukan di daerah tropis seperti Indonesia. Pada umumnya telur cacing bertahan di tanah yang lembab, tumbuh menjadi telur yang infektif dan siap masuk ke dalam tubuh manusia sebagai hospes definitif.

\subsection{Tinjauan Tentang Soil Transmitted Helminths (STH)}

Soil Transmitted Helminths (STH) adalah cacing golongan Nematoda yang penularannya melalui perantara tanah. Cacing yang banyak menginfeksi manusia adalah cacing gelang (A. lumbricoides), cacing tambang ( $N$. americanus dan $A$. duodenale), dan cacing cambuk ( $T$. trichiura), (Handayani, 2015).

\subsection{Morfologi}

\section{a. Cacing A. lumbricoides}

Morfologi dari cacing A. lumbricoides yakni cacing dewasa bentuknya mirip dengan cacing tanah, berwarna putih kecoklatan, jantan berukuran panjang 10 $31 \mathrm{~cm}$ dan betina berukuran panjang $22-35$ $\mathrm{cm}$.

Cacing A. lumbricoides memiliki 3 bibir, satu terletak mediodorsal dan dua ventrolateral. Cacing betina memiliki ekor lurus dan lancip, cacing jantan memiliki ekor melengkung. Pada posterior terdapat duri - duri halus yang disebut copulatory spikula. 


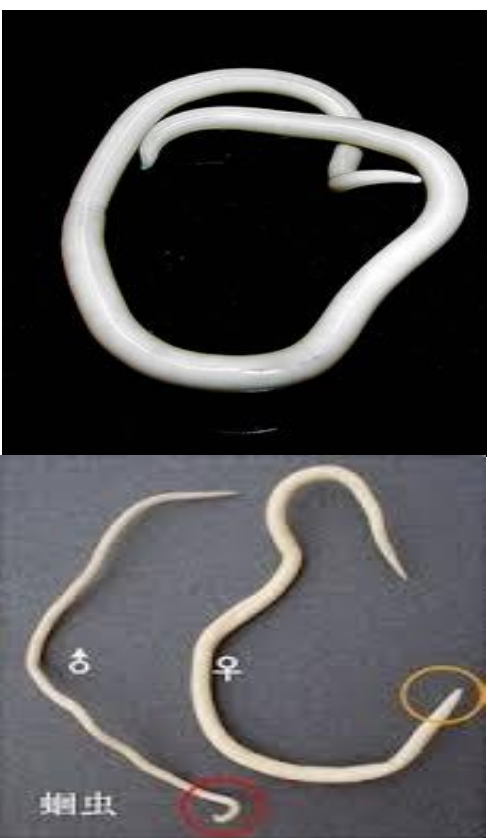

Gambar 2.1 : Cacing A. lumbricoides, (Soedarto, 1996).

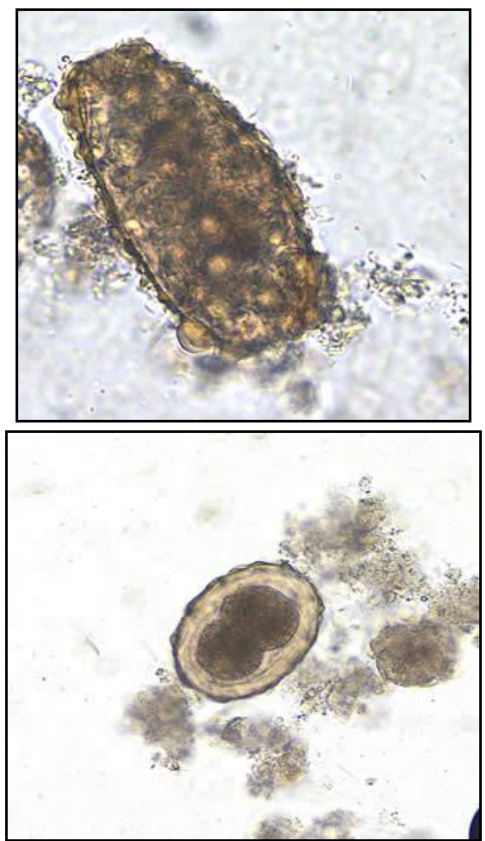

Gambar 2.2: Telur Cacing A. lumbricoides kanan : dibuahi, kiri : tidak dibuahi (Soedarto, 1996).

Telur cacing A. lumbricoides berbentuk lonjong berukuran 45-70 mikron $x \quad 35-50$ mikron. Di bagian terluar terdapat dinding telur yang tebal dengan permukaan bergerigi, berwarna cokelat karena menghisap zat warna empedu.

Terdapat 2 macam telur yakni telur yang dibuahi (Fertilized egg) dan yang tidak dibuahi (Unfertilized egg). Dimana telur yang dibuahi memiliki ukuran 60-45 mikron, bentuk agak lonjong dengan dinding luar tebal berwarna cokelat, dinding telur terdiri dari 3 lapisan. Terdapat lapisan albuminoid yang tebal, biasanya terdapat $1-4$ sel. Sedangkan telur yang tidak dibuahi berbentuk lonjong dari pada telur yang dibuahi, dinding tipis, lapisan albumin lebih tipis dari telur yang dibuahi, seluruh bagian dalam telur berisi penuh dengan granula. Telur infektif memiliki morfologi seperti telur yang dibuahi, berisi larva rhabditiform yang terbentuk 3 minggu setelah di tanah (Ideham dan Sahintam, 2007). Pada telur yang tidak dibuahi ini terdapat rongga udara. Ukurannya 80 × 55 mikron. Kadang - kadang di dalam tinja penderita ditemukan telur cacing $A$. lumbricoides yang telah hilang lapisan albuminnya, sehingga sulit dibedakan dari telur cacing lainnya. Adanya ovum yang besar menunjukkan ciri khas telur cacing $A$. lumbricoides .

b. Cacing T. trichiura

Cacing dewasa melekat pada mukosa usus penderita, terutama di daerah sekum dan kolon, dengan membenamkan kepalanya di dalam dinding usus. Kadang - kadang cacing ini ditemukan hidup di apendiks dan ileum bagian distal (Soedarto, 2009).

Morfologi dari cacing T. trichiura yakni cacing ini berbentuk seperti cambuk, yang jantan panjang tubuhnya sekitar $4 \mathrm{~cm}$ dan cacing betina berukuran panjang $5 \mathrm{~cm}$. Bagian ekor cacing jantan melengkung ke arah ventral, sedangkan cacing betina mempunyai bentuk membulat atau tumpul seperti koma (Soedarto, 2009). Pada cacing jantan $2 / 5$ bagian posterior gemuk dan $3 / 5$ bagian anterior kecil panjang seperti cambuk dengan kopulatrix spikula, sedangkan cacing betina ekornya lurus dan tumpul. 


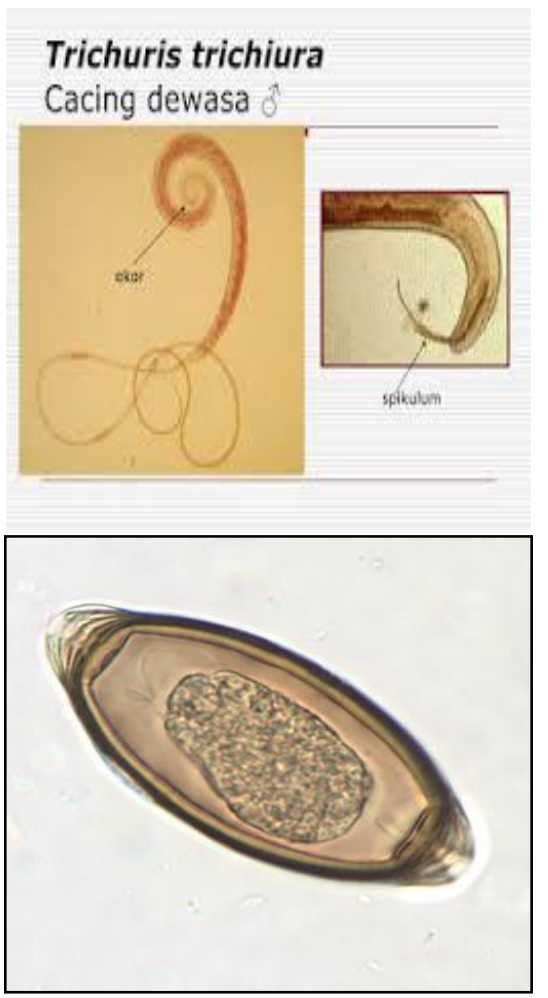

Gambar 2.3 : Cacing T. trichiura : kanan, telur cacing T. trichiura : kiri (Soedarto, 1996).

Telur cacing khas bentunya, mirip biji melon, berwarna cokelat, mempunyai dua kutub jernih yang menonjol, dengan ukuran 50 x 25 mikron (Soedarto, 2009). Bentuknya spesifik seperti tong atau tempayang dengan 2 buah plug (sumbat) yang jernih, dimana bagian dalam berisi larva atau sel telur yang baru terbantuk setelah 3 minggu di tanah.

c. Cacing Tambang

Cacing tambang yang dapat menginfeksi manusia adalah $N$. americanus dan $A$. duodenale. Spesies lain seperti $A$. braziliense dan $A$. caninum tidak dapat berkembang menjadi cacing dewasa di dalam tubuh manusia dan cacing ini cenderung menginfeksi anjing dan kucing.

Cacing dewasa hidup di dalam usus halus, terutama jejenum dan deudenum manusia dengan cara melekatkan diri pada membran mukosa menggunakan giginya, dan menghisap darah yang keluar dari luka gigitan.

1) Morfologi cacing N. americanus

Morfologi dari cacing $N$. americanus yakni cacing dewasa berbentuk silindris putih keabuan. Cacing betina berukuran panjang 9 - $13 \mathrm{~mm}$, sedangkan cacing jantan berukuran panjang antara 5 dan $11 \mathrm{~mm}$. Cacing jantan memiliki bursa kopulatrix alat bantu kopulasi yang terdapat di ujung posterior tubuh cacing (Soedarto, 2009). Cacing jantan berukuran $7-9 \mathrm{~mm}$ dan diameter $0,3 \mathrm{~mm}$ dan betina $9-11 \mathrm{~mm}$ dengan diameter $0,4 \mathrm{~mm}$.

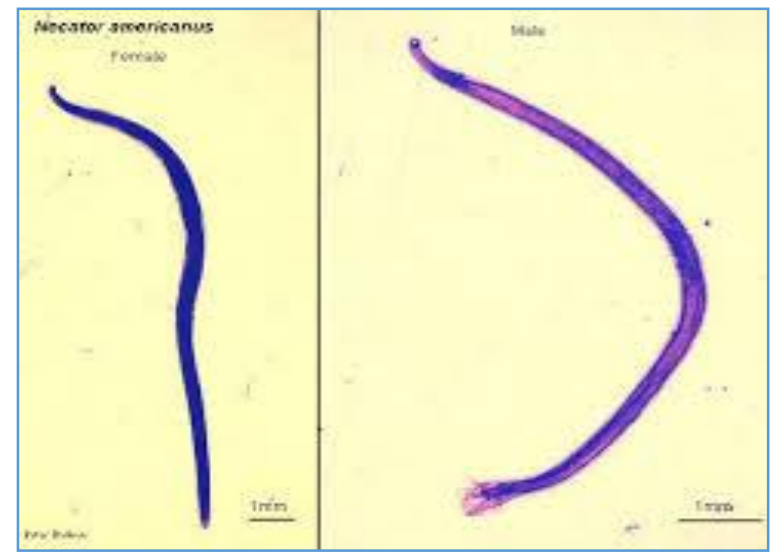

Gambar 2.4 : Cacing N. americanus (Soedarto, 1996).

Ukuran $N$. americanus yang bentuk tubuhnya mirip huruf $\mathrm{S}$, lebih kecil dan langsing dari pada $A$. duodenale. Pada $N$. americanus mempunyai 2 pasang alat pemotong atau yang disebut dengan cutting plate. Ujung posterior cacing jantan terdapat bursa kopulatrix dan sepasang spikula, sedangkan pada betina ujung posterior runcing, vulva terletak di bagian tengah tubuh .

2) Cacing A. duodenale

Cacing A. duodenale berbentuk ventral mirip huruf $\mathrm{C}$. Mulut dari A. duodenale mempunyai 2 pasang gigi. Berwarna merah muda atau cokelat muda keabu - abuan, 
cacing jantan panjangnya $8-11 \mathrm{~mm}$ dan diameternya $0,4-0,5 \mathrm{~mm}$. Cacing betina panjangnya $10-13 \mathrm{~mm}$ dan diameternya $0,6 \mathrm{~mm}$. Ujung posterior cacing betina tumpul dan cacing jantan memiliki bursa kopulatrix.

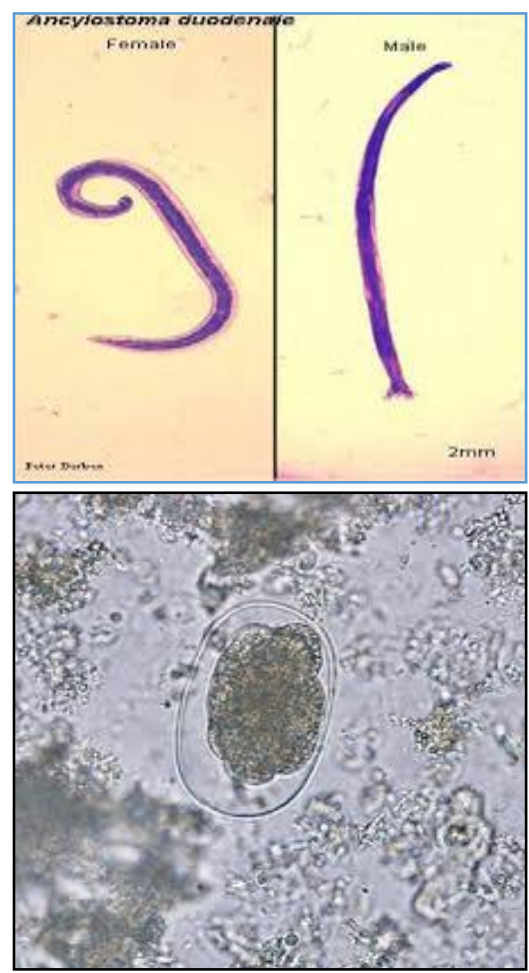

Gambar 2.5 Cacing A. duodenale dan Telur cacing tambang (Soedarto, 1996).

Telur cacing A. duodenale dan $N$. americanus sukar dibedakan bentunya. Telur berbentuk lonjong, tidak berwarna, berdinding tipis, tembus sinar, berisi embrio, dengan ukuran 65 x 40 mikron. Perbedaan morfologi antara A. duodenale dan $N$. americanus terletak pada bentuk tubuh, rongga mulut dan bursa kopulatriks.

\subsection{Siklus Hidup}

a. Siklus hidup cacing A. lumbricoides

Proses penularan Ascariasis pada manusia dapat terjadi melalui beberapa jalan, yaitu telur infektif masuk mulut bersama makanan dan minuman yang tercemar, melalui tangan yang kotor tercemar terutama pada anak, atau telur infektif terhirup melalui udara bersama debu.

Telur yang dikeluarkan oleh cacing melalui tinja dalam lingkungan yang sesuai akan berkembang menjadi embrio dan menjadi larva yang infektif. Apabila karena suatu sebab telur tersebut tertelan oleh manusia, maka di dalam usus larva akan menetas, keluar dan menembus dinding usus halus menuju ke sistem peredaran darah. Larva akan menuju ke paru, trakea, faring dan tertelan masuk ke esofagus hingga sampai ke usus halus. Perjalanan siklus hidup cacing ini berlangsung selama $65-70$ hari.

Untuk lebih jelasnya siklus hidup cacing gelang dapat dilihat seperti di bawah ini:

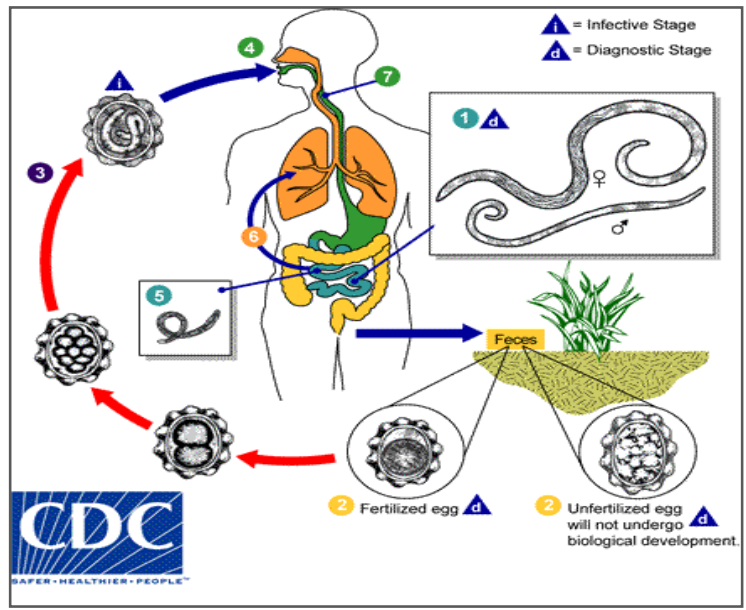

Gambar : Siklus hidup cacing A. lumbricoides. (Soedarto, 1996)

b. Cacing T. trichiura

Proses penularan cacing $T$. trichiura yaitu apabila manusia menelan telur yang matang, maka telur akan menetaskan larva yang akan berpenetrasi pada mukosa usus halus selama 3 - 10 hari. Selanjutnya larva akan bergerak turun dengan lambat untuk menjadi dewasa di sekum dan kolon ascendens. Siklus hidup dari telur menjadi cacing dewasa memerlukan waktu sekitar 3 
bulan. Di dalam sekum dan telur - telur ini keluar bersama tinja. Pada lingkungan yang kondusif, telur akan matang dalam waktu 2 -4 minggu.

Untuk lebih jelasnya, siklus hidup $T$. trichiura dapat dilihat pada gambar di bawah ini :

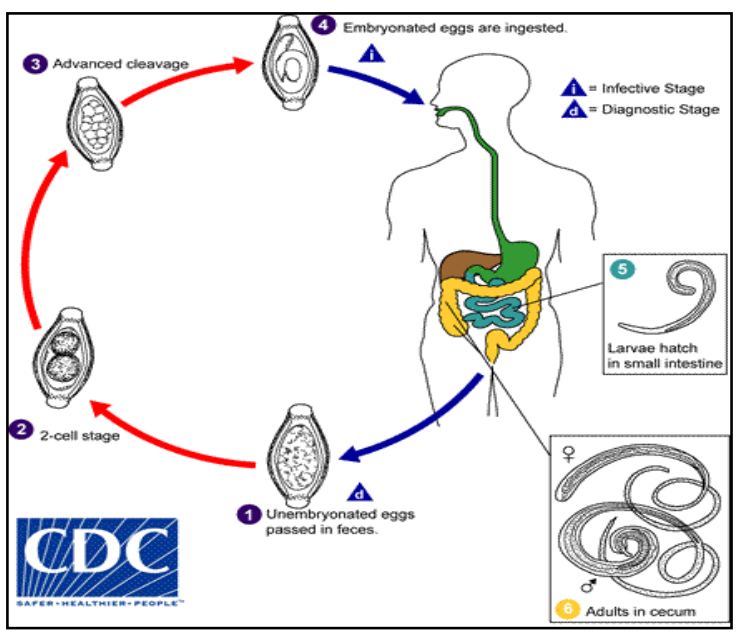

Gambar: Siklus hidup cacing T. trichiura

(Soedarto, 1996)

c. Cacing tambang

Proses penularan cacing tambang ini dimana cacing dewasa hidup dan bertelur di dalam $1 / 3$ atas usus halus, kemudian keluar melalui tinja. Telur akan berkembang menjadi larva di tanah yang sesuai suhu dan kelembabannya. Larva bentuk pertama adalah rhabditiform yang akan berubah menjadi filariform. Dari telur menjadi filariform memerlukan waktu selama 5- 10 hari. Larva akan memasuki tubuh manusia melalui kulit (terutama telapak kaki) untuk selanjutnya masuk ke peredaran darah manusia. Selanjutnya larva akan ke paru, naik ke trakea, berlanjut ke faring, kemudian larva tertelan ke saluran pencernaan. Larva bisa hidup dalam usus sampai delapan tahun dengan menghisap darah ( 1 cacing $=0,2$ $\mathrm{ml} / \mathrm{hari})$. Cara infeksi kedua yang bukan melalui kulit adalah tertelannya larva (terutama A. duodenale) dari makanan atau minuman yang telah tercemar
Untuk lebih jelasnya siklus hidup cacing tambang yakni :

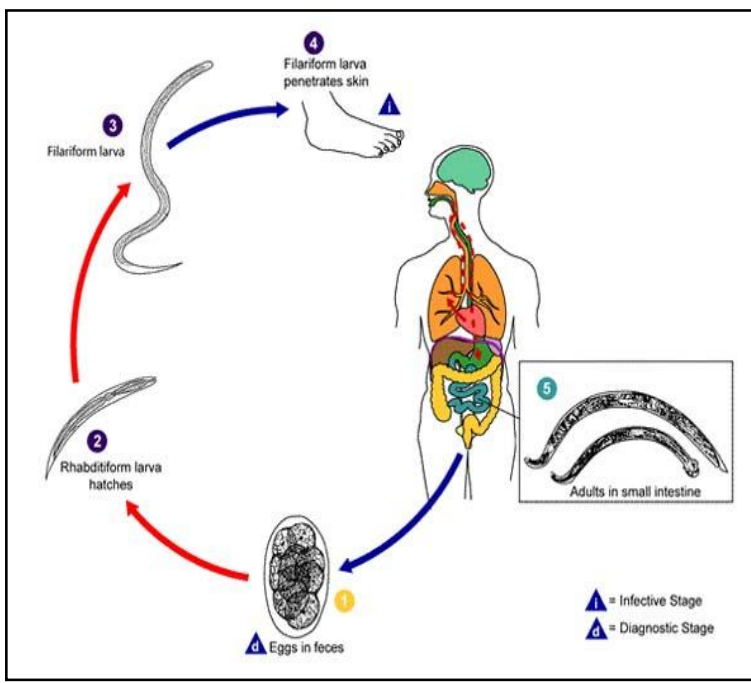

Gambar : Siklus hidup cacing tambang (Soedarto, 1996).

\subsection{Respon Imunitas pada Cacing}

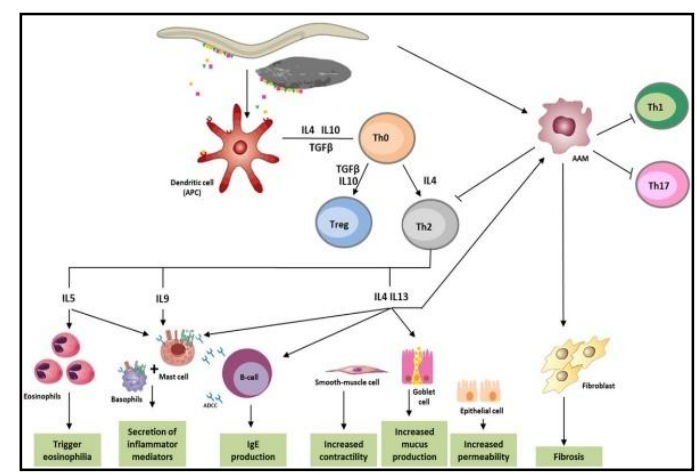

(Gambar 2.9 : Respon imun pada cacing, sumber dari Maizels\&McSorley, 2012).

Mekanisme imun pada cacing Ascaris adalah antigen Ascaris yang dihasilkan oleh cacing dewasa akan merangsang respon imun tubuh berupa sel Th2 yang akan menghasilkan eosinofilia, IgA, IgE, mastositosis dan mengeluarkan sekresi mucous melalui aktivasi sitokin IL-4, IL-5, 
dan IL-13. Peningkatan eosinofil sangat dipengaruhi oleh IL-5 sebagai mediator, sedangkan IL-4 IL13 sangat mempengaruhi perubahan fisiologi dalam saluran cerna seperti peningkatan permeabilitas mukosa dan kontraksi otot usus halus sehingga cacing akan didorong keluar dengan gejala berupa diare. Sementara itu, mekanisme imun tubuh melawan cacing $T$. trichiura hampir sama pada cacing ascaris, tetapi antigen yang berperan adalah antigen dari larva $T$. trichiura yang kemudian akan merangsang Th2 untuk memproduksi sitokin IL-5 yang sangat berperan sebagai mediator dari respon eosinofil.

Respon imun eosinofil terhadap cacing tambang sangat berperan baik dalam membunuh larva, maupun cacing tambang dewasa melalui respon imun sel Th2 yang kemudian akan menghasilkan IL-4, IL-5 dan IL-13. Kemudian IL-4 akan merangsang terbentuknya $\operatorname{IgE}$, IgG, dan IgM, sedangkan IL-5 akan merangsang produksi eosinofil. Proses eosinofilia akan terjadi setelah larva cacing telah masuk ke sirkulasi darah tubuh dan akan mencapai antara 38 sampai 64 hari.

\section{METODE PENELITIAN}

Pada penelitian ini menggunakan sampel feses, darah dan serum petani Dusun Sumberagung Kecamatan Gurah dengan jumlah 20 orang dan Dusun Janti Kecamatan Papar Kabupaten Kediri dengan jumlah 20 orang. Jenis penelitian ini adalah penelitian observasi analitik dengan studi Cross Sectional (observasi atau pengumpulan data sekaligus pada suatu saat artinya tiap subjek penelitian hanya diobservasi sekali saja dan pengukuran dilakukan terhadap status karakter atau variabel subjek pada saat pemeriksaan. Pengujian sampel feses dengan pemeriksaan sedimentasi, jumlah eosinofil dengan hematologi analyzer, kadar IL-5 dengan metode ELISA.

\subsection{Penjelasan sebelum pengambilan sampel feses dan darah}

Untuk keperluan pengambilan spesimen feses dan darah, terlebih dahulu dilakukan penjelasan kepada petani tentang pentingnya penelitian ini dan perlunya pengambilan spesimen feses dan darah.

\subsection{Pengambilan sampel feses petani Dusun Sumberagung Kecamatan Gurah dan Dusun Janti Kecamatan Papar Kabupaten Kediri}

Pengambilan sampel feses diambil feses segar dan tidak lebih dari 2 jam di tempatkan pada wadah yang bersih, bermulut lebar, tidak menyerap air di tutup yang rapat dan tidak bocor. Kemudian melakukan pencatatan identitas pasien meliputi nama, usia, jenis kelamin, tanggal dan waktu feses dikeluarkan.

\subsection{Bahan untuk pemeriksaan kadar IL-5}

Serum, tabung Serum Separator Tube (SST), antihuman IL-5 standar, sampel diluent, solution consetrate, biotinilated $A b$ reagen, streptavidin HRP, TMB substrat, stop solution.

\subsection{Bahan untuk hitung jumlah eosinofil Darah vena}

\subsection{Persiapan pengambilan sampel darah dan koleksi serum}

Pengambilan darah dilakukan pada vena yang cukup besar, lurus dan tampak jelas. Pengambilan sampel darah dengan menggunakan spuit $10 \mathrm{ml}$ diambil sebanyak $6 \mathrm{ml}$. Spesimen darah yang diperoleh di pindahkan secara hati-hati pada tabung sampel yang berwarna ungu yang berisi antikoagulan EDTA dan tabung warna merah yang berisi gel kemudian ditunggu hingga terjadi koagulasi dengan perkiraan waktu 1 jam. Serum yang terpisah kemudian diletakkan ke dalam tabung Eppendorf dan sisa padatan di centrifugasi pada $3000 \mathrm{rpm}$ selama 15 menit pada suhu $4^{\circ} \mathrm{C}$. Hasil 
sentrifugasi berupa supernatan di tambahkan ke dalam tabung Eppendorf berisi serum yang telah di dapat sebelumnya. Total serum yang diperoleh di sentrifugasi kembali pada $3000 \mathrm{rpm}$ selama 5 menit pada suhu $4^{\circ} \mathrm{C}$ dan disimpan dalam medical freezer suhu $-20^{\circ} \mathrm{C}$ hingga dilakukan uji kadar IL-5 serum menggunakan metode ELISA.

\subsection{Prosedur pemeriksaan sediaan feses}

Feses dimasukkan ke dalam tabung venoject sebanyak 1 gram, ditambahkan air, lalu dihancurkan dengan alat pengaduk hingga menjadi suspensi. Kemudian disaring suspensi tersebut dengan dua lapis kain kasa pada corong diatas gelas sedimen. Di tambahkan air kedalam tabung sedimen yang berisi suspensi sampai penuh, lalu tutup dengan drop karet. Kemudian di centrifus selama 2-3 menit dengan kecepatan $1500 \mathrm{rpm}$. Supernatan di buang dan bila cairan diatas sedimen masih keruh, diulangi prosedur di atas sampai menjadi jernih. Sedimen diaduk sampai homogen. Hasil supernatan kemudian diambil endapan dengan pipet pasteur dan di teteskan pada obyek glass ditutup dengan cover glass, di periksa di bawah mikroskop dengan pembesaran $10 \mathrm{x}$ dan bila perlu pembesaran 40x.

\subsection{Prosedur pemeriksaan hitung} eosinofil dengan hematology analyzer

Hematology Analyzer adalah alat untuk mengukur sampel berupa darah. Alat ini biasa digunakan dalam bidang kesehatan. Alat yang digunakan untuk memeriksa darah lengkap dengan cara menghitung dan mengukur sel darah secara otomatis berdasarkan impedansi aliran listrik atau berkas cahaya terhadap sel-sel yang di lewatkan. Mengukur sampel berupa darah. Pemeriksaan hematologi rutin seperti meliputi pemeriksaan hemoglobin, hitung sel leukosit, dan hitung jumlah sel trombosit.

Cara menggunakan hematology analyzer dengan menghubungkan kabel power ke stabilisator (stavo), menghidupkan alat (saklar on/off ada du sisi kanan atas alat) kemudian alat akan self check, pesan "please wait" akan tampil di layar dan alat akan secara otomatis melakukan self check kemudian background check dan dipastikan alat pada ready.

Cara kerja pemeriksaan sampel darah dengan sampel darah harus dipastikan sudah homogen dengan antikoagulan ekan tombol Whole Blood "WB" pada layar. Kemudian ditekan tombol ID dan masukkan no sampel, tekan enter kemudian ditekan bagian atas dari temapt sampel yang berwarna ungu untuk membuka dan meletakkan sampel dalam adaptor.Kemudian ditutup tempat sampel dan tekan "RUN". Hasil akan muncul pada layar secara otomatis dan mencatat hasil pemeriksaan.

\subsection{Prosedur penentuan kadar IL-5}

Untuk menentukan kadar IL-5 dalam penelitian ini menggunakan ELISA kit (Human IL-5 ELISA Kit, Bender Med System). Prosedur ELISA dilakukan sesuai prosedur pada kit mengikuti metode dengan beberapa modifikasi.menyiapkan microplate ELISA (96 well) dicuci dengan $300 \mu$ wash buffer. Memasukan larutan kurva standar, masing-masing sebanyak $100 \mu \mathrm{l} /$ well (biasanya well A-1 sampai $\mathrm{H}-1$ dan A-2 sampai $\mathrm{H}-2)$. $\mathrm{H}-1$ dan $\mathrm{H}-2$ digunakan untuk blanko. Tambahkan $100 \mu \mathrm{l} / \mathrm{ml} \mathrm{IL}-5$ standar pada well A-1 dan A-2 (duplo). Setelah dicampur, dari A-1 dan A-2 di ambil $100 \mu \mathrm{l}$ dan dimasukkan ke B-1 dan B-2. Setelah di campur, dari B-1 dan B-2 di ambil 100 $\mu 1$ dan dimasukkan ke C-1 dan C-2dan seterusnya hingga sampai G-1 dan G-2 karena $\mathrm{H}-1$ dan $\mathrm{H}-2$ di gunakan sebagai blanko. Dengan demikian terjadi pengenceran dengan kadar ml IL-5 standar berturut-turut 1000, 500, 250, 125, 63, 32, dan $16 \mathrm{pg} / \mathrm{ml}$. kemudian ambil dan masukkan $50 \mu \mathrm{l}$ sampel diluent pada well sampel dan tambahkan $50 \mu 1$ sampel. Di tambahkan $50 \mu \mathrm{l}$ biotin conjugate dan di inkubasi (shaker $200 \mathrm{rpm}$ ) selama 2 jam pada suhu ruang. Well microplate di cuci $3 \mathrm{x}$ 
dengan wash buffer $300 \mu \mathrm{l}$, kemudian tambahkan $100 \mu \mathrm{l}$ streptavidin-HRP pada setiap sampel, di inkubasi 1 jam pada shaker 200 rpm dengan suhu ruang. Well microplate dicuci $3 \mathrm{x}$ dengan wash buffer $100 \mu \mathrm{l}$ TMB sustrat solution pada semua well dan di inkubasi selama 10 menit pada suhu ruang. Kemudian di tambahkan stop solution $100 \mu \mathrm{l}$ untuk menghentikan reaksi. Setelah itu di ukur kadar IL-5 dengan menggunakan ELISA reader pada panjang gelombang $450 \mathrm{~nm}$ setelah di inkubasi selama 30 menit.

\section{HASIL DAN PEMBAHASAN}

4.1 Hasil Karakteristik Responden Yang Terinfeksi STH Dengan Kadar IL-5 Dan Jumlah Eosinofil Di Dusun Sumberagung Kecamatan Gurah Dan Dusun Janti Kecamatan Papar Kabupaten Kediri

Tabel 5.1 Karakteristik responden yang terinfeksi STH dengan kadar IL-5 dan jumlah eosinofil di Dusun Sumberagung Kecamatan Gurah dan Dusun Janti Kecamatan Papar Kabupaten Kediri.

\begin{tabular}{|l|c|c|c|}
\hline Karakteristik & $\begin{array}{c}\text { Dusun } \\
\text { Sumberagung }\end{array}$ & $\begin{array}{c}\text { Dusun } \\
\text { Janti }\end{array}$ & Jumlah \\
\hline Laki-laki & 6 & 4 & 10 \\
\hline Perempuan & 4 & 6 & 10 \\
\hline Umur: & - & 1 & 1 \\
\hline $21-30$ & 1 & - & 1 \\
\hline $31-40$ & - & 2 & 2 \\
\hline $41-50$ & 7 & 6 & 13 \\
\hline $51-60$ & 2 & 1 & 3 \\
\hline $61-70$ & 6 & 10 & 16 \\
\hline \begin{tabular}{l} 
Infeksi tunggal: \\
\hline $\begin{array}{l}\text { A. lumbricoide } \\
\text { s }\end{array}$
\end{tabular} & 1 & - & 1 \\
\hline T. trichiura & 1 & - & 1 \\
\hline Hookworm & 2 & - & 2 \\
\hline \begin{tabular}{l} 
Infeksi ganda: \\
\hline $\begin{array}{l}\text { A. } \\
\text { lumbricoides } \\
\text { T. trichiura }\end{array}$
\end{tabular} & & \\
\hline
\end{tabular}

\begin{tabular}{|l|l|l|c|}
\hline \multicolumn{4}{|l|}{ Tidak terinfeksi: } \\
\hline Laki-laki & 7 & 6 & 13 \\
\hline Perempuan & 3 & 4 & 7 \\
\hline
\end{tabular}

\subsection{Hasil Analisis Kadar IL-5 dan Jumlah Eosinofil Pada Petani Yang Terinfeksi dan Tidak Terinfeksi STH}

Tabel 5.2 Hasil Analisis kadar IL-5 dan jumlah eosinofil pada petani yang terinfeksi dan tidak terinfeksi STH).

\begin{tabular}{|c|c|c|c|c|c|}
\hline \multicolumn{2}{|c|}{ Infeksi } & Mean & Std. Dev & Min & Max \\
\hline \multirow{3}{*}{ Eosinofil } & + & 4,2250 & 2,96947 & 0,40 & 12,40 \\
\cline { 2 - 6 } & - & 1,9550 & 1,02520 & 0,70 & 4,20 \\
\hline \multirow{3}{*}{ IL-5 } & + & 6,4150 & 2,94677 & 3,20 & 13,10 \\
\cline { 2 - 6 } & - & 3,1550 & 0,63119 & 2,20 & 4,10 \\
\hline
\end{tabular}

Keterangan:

$+\quad$ : Terinfeksi STH

_ $\quad$ : Tidak terinfeksi STH

Tabel 5.2 menunjukkan hasil penelitian kadar IL-5 pada petani yang terinfeksi STH lebih tinggi jumlahnya yaitu 6,4150 dari pada petani yang tidak terinfeksi STH yaitu 3,1550. Berdasarkan uji normalitas data terdistribusi normal sehingga dilakukan uji parametrik untuk dua sampel bebas Kolmogorof Smirnov. Berdasarkan uji statistik terdapat perbedaan bermakna antara jumlah eosinofil petani yang terinfeksi dan petani yang tidak terinfeksi STH dengan nilai $\mathrm{p}<0,05$.

Hasil jumlah eosinofil pada petani yang terinfeksi dan tidak terinfeksi STH. Hasil penelitian diperoleh jumlah eosinofil pada petani yang terinfeksi STH lebih tinggi jumlahnya yaitu 4,2250 dari pada petani yang tidak terinfeksi STH yaitu 1,9550. Berdasarkan uji normalitas data terdistribusi normal sehingga dilakukan uji parametrik untuk dua sampel bebas Kolmogorof Smirnov. Berdasarkan uji statistik terdapat perbedaan bermakna antara jumlah eosinofil 
petani yang terinfeksi dan tidak terinfeksi STH dengan nilai $\mathrm{p}<0,05$.

\subsection{Hasil Analisis Korelasi Kadar IL-5 dan Jumlah Eosinofil Pada Petani Yang Terinfeksi dan Tidak Terinfeksi STH}

Data kadar IL-5 dan jumlah eosinofil petani yang terinfeksi dan tidak terinfeksi STH terlebih dahulu dilakukan uji $t$ independen tetapi data terdistribusi tidak normal selanjutnya dilakukan uji non parametrik Mann Whitney dengan hasil seperti tercantum dalam tabel 5.3. Berdasarkan hasil uji statistik non parametrik Mann Whitney menunjukkan bahwa ada perbedaan kadar IL-5 dan jumlah eosinofil pada petani yang terinfeksi dan tidak terinfeksi STH dimana kadar IL-5 dan jumlah eosinofil yang terinfeksi lebih tinggi daripada yang tidak terinfeksi STH dengan menunjukkan hasil yang signifikan nilai eosinofil $(\mathrm{p}=0,014)$ dan hasil signifikan kadar IL-5 ( $\mathrm{p}=0,000)$ dimana $\mathrm{p} 0,000$ $<0,05$ dan $\mathrm{p} 0,014<0,05$ sehingga kadar IL-5 dan jumlah eosinofil berpengaruh terhadap petani yang terinfeksi STH.

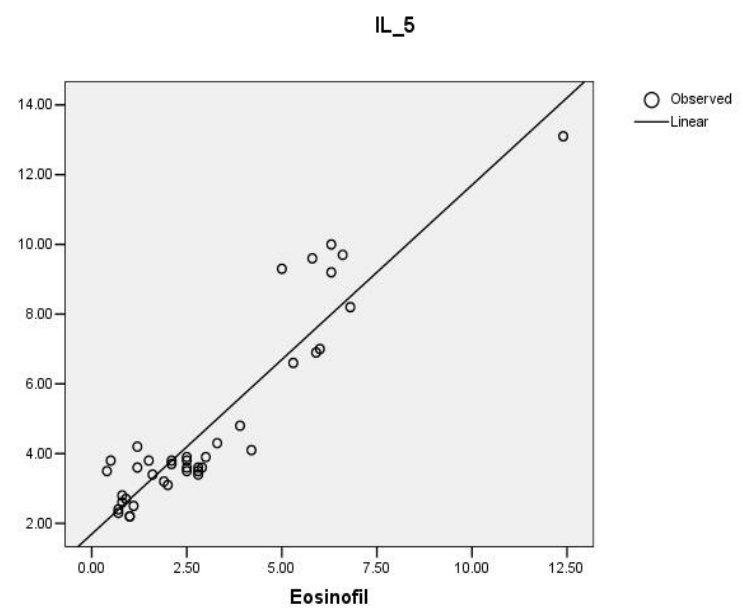

(Grafik 5.1 Kadar IL-5 dengan Jumlah eosinofil pada petani yang terinfeksi dan tidak terinfeksi STH).

Dari grafik 5.1 diatas terdapat korelasi positif yang kuat $(r=0,833)$ antara kadar IL-5 dan jumlah eosinofil. Secara statistik terdapat hubungan yang bermakna sehingga hubungannya sangat erat dimana kenaikan kadar IL-5 juga diikuti dengan kenaikan jumlah eosinofil.

\subsection{Hasil Analisis Hubungan Antara Jenis Spesies Cacing dan Jumlah Spesies Dengan Kadar IL-5 dan Jumlah Eosinofil Pada Petani Yang Terinfeksi STH}

Tabel 5.4 Hasil Analisis hubungan antara jenis spesies cacing dan jumlah spesies dengan kadar IL-5 dan jumlah eosinofil pada petani yang terinfeksi STH.

\begin{tabular}{|l|c|c|}
\hline \multicolumn{1}{|c|}{ Spesies } & $\begin{array}{c}\text { IL-5 } \\
(\mathrm{pg} / \mathrm{nm})\end{array}$ & $\begin{array}{c}\text { Eosinofil } \\
(\%)\end{array}$ \\
\hline $\begin{array}{l}\text { A. lumbricoides } \\
\text { T. trichiura }\end{array}$ & $3,6-4,3$ & $1,2-3,3$ \\
\hline A. lumbricoides & $3,2-13,1$ & $0,4-12,4$ \\
\hline T. trichiura & 9,3 & 5,0 \\
\hline Hookworm & 6,9 & 5,9 \\
\hline
\end{tabular}

Tabel 5.4 menunjukkan rerata jenis spesies cacing

A. lumbricoides dan T. trichiura dengan kadar IL-5 sebesar 3,6-4,3 dan jumlah eosinofi sebesar 1,2-3,3, jenis spesies A. lumbricoides dengan kadar IL-5 sebesar 3,2-13,1 dan jumlah eosinofil sebesar 0,4-12,4, jenis spesies cacing $T$. trichiura dengan kadar IL-5 sebesar 9,3 dan jumlah eosinofil sebesar 5,0, jenis spesies cacing Hookworm dengan kadar IL-5 sebesar 6,9 dan jumlah eosinofil sebesar 5,9.

\section{PEMBAHASAN}

\subsection{Hubungan Antara Jenis Kelamin, Asal Daerah, Usia Dengan Kejadian Infeksi STH dan Spesies STH.}

Hasil penelitian ini menunjukkan bahwa tidak ada hubungan antara jenis kelamin, asal daerah, usia dengan kejadian infeksi STH. Hal ini terlihat pada tabel 5.1 infeksi STH terdistribusi merata berdasarkan karakteristik responden. Penularan infeksi STH melalui perantara tanah, oleh karena itu setiap orang yang berhubungan langsung dengan tanah sangat berpotensi terinfeksi STH. Seperti dikatakan 
oleh Rawina, (2012) bahwa cacing STH sering dijumpai pada orang yang sering kontak dengan tanah.

Banyak faktor yang menyebabkan terjadinya infeksi STH, tetapi secara umum terdapat dua faktor yang utama sebagai indikasi seseorang terinfeksi cacing antara lain yaitu faktor eksternal dan faktor internal. Jika dilihat dari faktor eksternal perilaku sangat berpengaruh terhadap kejadian infeksi cacing STH.(Rawina, (2012) berpendapat bahwa masih tingginya infeksi cacing STH disebabkan rendahnya tingkat hygiene pribadi (perilaku hidup sehat dan bersih). Personal hygiene merupakan faktor penting dalam peningkatan prevalensi penyakit yang disebabkan oleh cacing (Widjana dan Sutisna, 2003).

\subsection{Perbedaan Kadar IL-5 dan Jumlah Eosinofil Pada Petani Yang Terinfeksi dan Tidak Terinfeksi STH}

Berdasarkan tabel 5.7 mean kadar IL-5 pada petani yang terinfeksi STH lebih tinggi $(6,4150)$ dari pada petani yang tidak terinfeksi STH $(3,1550)$ dengan nilai $p<0,05$. Hal ini berarti terdapat perbedaan bermakna antara mean kadar IL-5 petani yang terinfeksi dan tidak terinfeksi STH.

Jumlah eosinofil pada petani yang terinfeksi STH lebih tinggi yaitu 4,2250 dari pada petani yang tidak terinfeksi STH yaitu 1,9550 dengan nilai $\mathrm{p}<0,05$. Hal ini menunjukkan bahwa terdapat perbedaan bermakna antara jumlah eosinofil petani yang terinfeksi dan tidak terinfeksi STH. Penelitian ini serupa dengan penelitian Cooper et al, (2000) telah meneliti terhadap 73 responden remaja yang terinfeksi oleh cacing $A$. lumbricoides dengan melakukan perbandingan terhadap 40 responden yang tidak terinfeksi oleh A. lumbricoides. Hasil penelitian menunjukkan rerata kadar IL-5 pada responden yang terinfeksi oleh A. lumbricoides yaitu 4,6 $\mathrm{pg} / \mathrm{ml}$, sedangkan 40 responden yang tidak terinfeksi A. lumbricoides rerata kadar IL-5 adalah $1,8 \mathrm{pg} / \mathrm{ml}$ dan uji statistik menunjukkan terdapat perbedaan dengan nilai $p<0,05$.
Pada umumnya pertahanan terhadap banyak infeksi cacing diperankan oleh aktivasi sel Th2. Cacing merangsang subset $\mathrm{Th} 2$ sel $\mathrm{CD}^{+}$yang akan melepaskan IL-4 dan IL-5. Pada infeksi cacing usus secara eksperimen memperlihatkan stimulasi respon imun hospes ke arah Th2. Antigen Precenting Cell (APC) berupa sel dendrit, saat terjadi infeksi cacing akan mempresentasikan molekul antigen cacing bersama molekul MHC klas II pada sel $\mathrm{T}$ naïve (Th0), maka akan terjadi proliferasi dan differensiasi menjadi Th1 dan Th2. Th2 yang berproliferasi dan differensiasi akan mengeluarkan sitokin IL-4 dan IL-5 (Roit, 2002).

Peningkatan jumlah eosinofil pada responden yang mendapatkan infeksi helminth merupakan aktivasi dari IL-5. Hasil penelitian menunjukkan bahwa terjadi peningkatan jumlah eosinofil pada responden yang terinfeksi STH. (Medeiros et al, 2005) berpendapat bahwa jumlah eosinofil yang tinggi sering ditemukan pada kecacingan yang bersifat kronis.

Pada infeksi cacing yang bersifat akut diawali dengan proliferasi dan differensiasi sel Th0 menjadi Th1 dan Th2 dengan dominasi kearah Th2. Sel Th2 yang terbentuk akan mengekpresikan IL-4 dan IL-5. IL-4 akan berperan dalam membantu sel B untuk memproduksi IgE. Dalam waktu yang bersamaan IL-5 akan meningkatkan jumlah eosinofil sehinggan terjadi eosinofilia (Sher dan Scott, 1993).

Pada infeksi kronik terjadi perubahan mekanisme yaitu sel Th2 merespon sel dendrite yang bertindak sebagai APC. Oleh sel Th2 akan terhambat ekspresi IL-5 sehingga sel eosinofil tidak terbentuk. Pada infeksi kronik ini terdapat keterlibatan sel Treg yang menghasilkan IL-10 dan TGF- $\beta$. Sitokin IL-10 berperan dalam class switching respon antibody. Sel B yang sebelumnya memproduksi IgE menjadi memproduksi IgG4. Antibodi IgG4 ini akan menghambat degranulasi sel efektor sehingga atopi tidak terjadi. Selanjutnya TGF- $\beta$ berperan 
dalam menekan respon seluler baik Th1 maupun Th2 (Yazdanbakhsh, 2001).

Hasil yang diperoleh pada penelitian ini sesuai dengan penelitian yang dilakukan oleh Teo dkk, (1985) yang meneliti 47 anak laki-laki dengan eosinofilia, $92 \%$ pada penderita eosinofilia dan alergi diantaranya mengalami kecacingan. Peningkatan jumlah eosinofil lebih tinggi pada anak dengan kecacingan daripada anak dengan alergi.

\subsection{Korelasi Kadar IL-5 dan Jumlah Eosinofil Pada Petani Yang Terinfeksi STH}

Berdasarkan hasil penelitian korelasi kadar IL-5 dengan jumlah eosinofil pada petani yang terinfeksi dan tidak terinfeksi STH dilihat pada grafik 5.1. Analisis statistik menunjukkan terdapat korelasi positif yang kuat dengan nilai $\mathrm{r}=0,833$ berarti terdapat hubungan yang bermakna dengan nilai $\mathrm{p}<0,05$ antara kadar IL5 dan jumlah eosinofil pada petani yang terinfeksi dan tidak terinfeksi STH.

Hubungan yang sangat erat antara peningkatan kadar IL-5 yang diikuti dengan kenaikan jumlah eosinofil dikarenakan fungsi dari IL-5 dan eosinofil adalah sebagai pelindung terhadap paparan berulang oleh parasit usus. Persentasi sel eosinofil ke jalur peradangan pada saluran pencernaan tergantung pada berbagai respon sitokin khususnya oleh sel Th2 dan produk sel endotel, IL-4, IL-5 dan IL-13. Sitokin IL-5 diproduksi oleh sel T limphosit $\mathrm{Th} 2 \mathrm{CD}^{+}$serta oleh sel lain (termasuk eosinofil) yang memberikan sinyal penting untuk ekspansi dan pergerakan dari sumsum tulang setelah terpapar baik allergen maupun infeksi oleh cacing. Sitokin IL-5 bertindak lebih cepat untuk meningkatkan sirkulasi eosinofil dengan pergerakan cara marginasi (MacDonald, 2002).

\subsection{Hubungan Antara Spesies Cacing dan Jumlah Spesies Pada Kadar IL-5 dan Jumlah Eosinofil Pada Petani Yang Terinfeksi STH}

Berdasarkan hubungan antar jenis spesies dan jumlah spesies dengan kadar IL-5 dan jumlah eosinofil pada table tidak menunjukkantidak terdapat perbedaan kadar IL5 dan jumlah eosinofil pada infeksi ganda $A$. lumbricoides dan $T$. trichiura dan infeksi tunggal A. lumbricoides, T. trichiura, Hookworm. Hanya ditemukan satu responden yang terinfeksi A. lumbricoides yang kadar IL-5 dan jumlah eosinofilnya sangat tinggi. Hal ini kemungkinan dikarenakan ada adanya infeksi lain atau alergi. Mekanisme imun pada infeksi $A$. lumbricoides yang disebabkan oleh cacing dewasa akan merangsang respon imun tubuh berupa sel Th2 yang akan menghasilkan eosinofilia, IgA, IgE, mastositosis dan mengeluarkan sekresi mucous melalui aktivasi sitokin IL-4, IL-5, dan IL-13. Peningkatan eosinofil sendiri sangat dipengaruhi oleh IL-5 sebagai mediator, sedangkan IL-4 dan IL-13 sangat mempengaruhi perubahan fisiologi dalam saluran cerna seperti peningkatan permeabilitas mukosa dan kontraksi otot usus halus sehingga cacing akan didorong keluar dengan gejala berupa diare (Bradley dan Jackson, 2004). Prevalensi infeksi A. lumbricoides paling tinggi pada populasi dengan sanitasi yang buruk dan pada penggunaan kotoran manusia digunakan sebagai pupuk tanaman.

Pada infeksi T. trichiura, mekanisme imun tubuh melawan cacing $T$. trichiura hampir sama dengan infeksi A. lumbricoides tetapi antigen yang berperan adalah larva cacing $T$. trichiuris yang kemudian akan merangsang Th2 untuk memproduksi IL-5 yang sangat berperan sebagai mediator dari respon eosinofil. Pada $T$. trichiura respon imun sel mast tidak berperan sama sekali untuk melawan cacing (Bradley dan Jackson, 2004). Telur cacing T. trichiura ini tumbuh di tanah liat, tempat yang lembab dan teduh dengan suhu rata-rata $30^{\circ} \mathrm{C}$. Pada daerah yang banyak menggunakan feses manusia 
sebagai pupuk tanaman merupakan jalur infeksi yang tepat. Frekuensi infeksi cacing ini di Indonesia sangat tinggi. Di berbagai daerah pedesaan di Indonesia frekuensi cacing ini hingga mencapai 30-90\%.

Pada infeksi Hookworm (cacing tambang) respon imun pada cacing tambang sangat berperan baik dalam membunuh larva maupun cacing dewasa melalui respon imun sel Th2 yang kemudian akan menghasilkan IL-4, IL-5 dan IL-13. Kemudian IL-4 akan merangsang terbentukya IgE, IgG dan IgM, sedangkan IL-5 akan merangsang produksi eosinofil. Proses eosinofilia akan terjadi setelah larva cacing masuk ke sirkulasi darah tubuh dan akan tercapai antara 38 sampai 64 hari (Bethony dkk, 2006).

\section{KESIMPULAN}

\subsection{Kesimpulan}

Berdasarkan hasil penelitian yang telah dilakukan dapat disimpulkan

1. Kadar IL-5 pada petani yang terinfeksi STH lebih tinggi dari pada petani yang tidak terinfeksi STH

2. Jumlah eosinofil pada petani yang terinfeksi STH lebih tinggi dari pada petani yang tidak terinfeksi STH

\subsection{Saran}

1. Perlu dilakukan penelitian lebih lanjut mengenai jumlah telur cacing pada feses untuk mengetahui derajat kepekaan infeksi

2. Meningkatkan hygiene dan sanitasi pribadi dan lingkungan

\section{DAFTAR PUSTAKA}

Abbas \& Lichtman. 2007. Cellular and Molecular Immunology. Philadelphia: Elvesier Saunders
Amry dkk, 2013. Gambaran Parasit Soil Transmitted Helminths Dan Tingkat Pengetahuan, Sikap Serta Tindakan Petani Sayur Di Desa Waiheru Kecamatan Baguala Kota Ambon. Kesehatan Lingkungan : Universitas Hasanuddin

Bariah, Ideham dan Sahintam (Ed). 2007. Buku Penuntun Praktis Parasitologi Kedokteran. Surabaya : Airlangga University Press

Bethony J, dkk. 2006. Soil Transmitted Helminth Infection: Ascariasis, Trichuriasis, and Hookworm. Lancer

Bradley JE. Jackson JA. 2004. Immunity, Immunogerulation and the Ecology of Trichuriasis and Ascariasis. Parasit Immunol

CDC. 2013. Laboratory Identification of Parasitic Diseases of Public Health Concern. http://dpd.cdc.gov/dpdx. Diakses tanggal 7 Februari 2016 Pukul 13:00 WIB

Cooper PJ, Chico m, Sandoval C, Espinel I, Guevara A, Levine et al. 2000. Human Infections With Ascaris lumbricoides is Associated with a Polarized, cytokins respons. The Journal of Infections Diseases

Dachi, R.A. 2005. Hubungan Perilaku Anak Sekolah Dasar Terhadap Infeksi Cacing Perut Di Kecamatan Palipi Kabupaten Samosir Tahun 2005. Jurnal Mutiara Kesehatan Indonesia. vol.1 .(2), Hal 1- 7

Gandasoebrata, R. 2008. Penuntun Laboratorium Klinik. Jakarta: Penerbit Buku Dian Rakyat

Handayani, Dwi, dkk. 2015. Hubungan Infeksi Soil Transmitted Helminths (STH) dengan Prestasi Belajar pada Siswa SDN 169 di Kelurahan Gandus Kecamatan Gandus Kita Palembang. Jurnal ISSN 0852-3835 MKS Th. 47 No. 2 , April Tahun 2015 
Hidajati, Sri, dkk. 2014. Atlas Parasitologi Kedokteran. Jakarta: Penerbit Buku Kedokteran EGC

Husodo SY, 2006 dalam Sandi, Adytri, 2014. Gambaran Nilai Hematokrit Dengan Menggunakan Metode Mikro Pada Buruh Tani Di Desa Kandat Kabupaten Kediri. Kediri : Institut Ilmu Kesehatan Bhakti Wiyata Kediri

Irianto, Koes. 2013. Parasitologi Medis. Bandung: Alfabeta

KEPMENKES RI. 2006. Pedoman Pengendalian Cacingan Nomor 424/MENKES/SK/VI/2006. Menteri

Kesehatan Republik Indonesia

Kumoro, Adhi. 2014. Parasitologi Praktikum Analis Kesehatan. Jakarta: Penerbit Buku Kedokteran EGC

Kuntoro, Haji. 2010. Metode Sampling dan Penentuan Besar Sampel.Surabaya: Penerbit Pustaka Melati Surabaya

Loukas A, Prociv P. 2001. Immune Respon in Hookworm Infection. Clin Mikrobiol

MacDonald AS, Araujo Ml, Pearce EJ. 2002. Immunology of Parasitic Infetions. Infections and Immunity.

Maizel RM, Yazdanbakhsh M. 2003. Immune Regulation by Helminth Parasites Cellular and Molekular Mechanism, Nature Review

Mc Sorley HJ, Maizels RM. 2012. Helminth Infection and Host Immune Regulation. Clin Microbiol

Meideros D, Almerinda Selvia, Rizzo JA, Motta ME, Oliveira FHB, Sarinho ES. 2005. Total IgE level in Respiratory Allergy; Study of Patiens at High Risk for Helminth Infection J De Pediatric
Moreau E, Chauvin A. 2010. Immunity Against Helminths: Interaction with the Host and the Intercurrent Infections. $\mathrm{J}$ Biomed Biotech

Notoatmodjo. 2012. Metodologi Penelitian Kesehatan. Jakarta : PT Rineka Cipta

Nurtukbroto. 2006 dalam Sandi, Adytri. 2014. Gambaran Nilai Hematokrit Dengan Menggunakan Metode Mikro Pada Buruh Tani Di Desa Kandat Kabupaten Kediri. Kediri : Institut Ilmu Kesehatan Bhakti Wiyata Kediri

Nutman TB. 2007. Evaluation and Differential Diagnosis of Marked, Persistent Eosinophilia. Immunol Allergy Cklin North Am

Pearce N, Ait Khaled N, Beasly R, Malool J, Keil U. 2007. Worldwide trend in the Prevalence of Astma symptoms; phase III of the Internatoinal Studt of Asthma and Allergen in Childhood

Roit I. 2002. Imunologi, Essential Immunology. Edisi 8. Jakarta: Penerbit Widya Medika

Soedarto. 2009. Penyakit Menular di Indonesia Cacing Protozoa Bakteri Virus Jamur. Surabaya : Sugung Seto

Staff Pengajar FKUI(Ed). 2006. Parasitologi Kedokteran Edisi 3. Jakarta : Universitas Indonesia

Soemarmo dkk. 2008. Buku Ajar Infeksi dan Pediatri Tropis Edisi Ke 2. Jakarta : Bagian Penerbit IDAI

Syahyuti. 2013. Pemahaman Terhadap Petani Kecil Sebagai Landasan Kebijakan Pembangunan Pertanian. Bogor : Pusat Sosial Ekonomi dan Kebijakan Pertanian

Teo CG, Singh M, Ting WC, Ho LC, Ong YW. 1985.Evalution of the Common Condition Associated with Eosinophilia. J Clin Pathol 
Jurnal Biosains Pascasarjana Vol. 18 (2016) pp

(C) (2016) Sekolah Pascasarjana Universitas Airlangga, Indonesia

Widjana DP, Sutisna P. 2000. Prevalence of Soil Transmitted Helminth Infection in the rural population of Bali, Indonesia. Southeast Asian J Trop Med Public Health

Widoyono (Ed). 2011. Penyakit Tropis Epidemologi, Penularan, Pencegahan dan Pemberantasannya Edisi Kedua. Jakarta: Erlangga

Yazdanbakhsh M, Van den Biggelaar A, Maizels RM. 2001. Th2 responses without atopy: immunoregulation in chronic helminth infection and reduced allergic disease. Trend Immunol.

Zulkoni, Akhsin. 2011. "Parasitologi untuk Keperawatan, Kesehatan Masyarakat, dan Teknik Lingkungan”. Yogyakarta : Nuha Medika 